\title{
Rada Polityki Pieniężnej jako szczególny organ państwa
}

\begin{abstract}
Streszczenie: Artykuł poświęcony jest Radzie Polityki Pieniężnej. Celem opracowania jest analiza ustrojowej pozycji Rady. Określenie statusu prawnego RPP stanowi początek rozważań. W dalszej części przedstawiono model kadencyjności i skład osobowy RPP. W tym kontekście omówione zostały propozycje zmian zawarte w projekcie ustawy o NBP. Istotną częścią artykułu jest kwestia wymogów merytorycznych stawianych członkom RPP. Podkreślają one pozycję Rady na tle innych organów państwa. Zakończenie zawiera wnioski potwierdzające, że RPP to szczególny organ państwa. Autor wskazuje również, że należałoby dokonać pewnych zmian wzmacniających działanie RPP, a mianowicie konstytucyjnie uregulować liczbę wybieranych do niej członków przez uprawnione do tego organy i uregulować kwestie kompetencji prawotwórczych.
\end{abstract}

Słowa kluczowe: instytucje państwa, bank centralny, polityka gospodarcza

$\mathbf{P}$ rzemiany ustrojowe, jakie miały miejsce w Polsce po 1989 r. sprawiły, że pojawiły się szczególne organy państwowe, które zostały wyłączone z administracji rządowej. Takim organem jest Rada Polityki Pieniężnej (RPP). Jest ona jednym z trzech obok Prezesa NBP, Zarządu NBP organem banku centralnego w Polsce. Wyodrębnienie RPP jako podmiotu odpowiedzialnego za prowadzenie polityki pieniężnej stanowi wielkie osiagnięcie. W znaczący sposób ogranicza ono wpływ organów władzy wykonawczej i ustawodawczej na jej kształt.

Celem opracowania jest analiza ustrojowej pozycji Rady Polityki Pieniężnej. Realizacja tego celu wymaga zastosowania adekwatnych metod badawczych. W artykule zastosowano metodę instytucjonalno-prawną, systemową i komparatywną. Metoda instytucjonalno-prawna pozwoliła na analizę przepisów prawnych, w oparciu o które działa RPP, czyli Konstytucji RP i ustawy o Narodowym Banku Polskim. Za pomocą metody systemowej ukazano RPP w systemie ustrojowym Polski jako instytucję odpowiedzialną za prowadzenie polityki pieniężnej państwa. Metoda komparatywna pomogła w ustaleniu cech charakterystycznych dla Rady Polityki Pieniężnej jako szczególnego organu państwa oraz porównaniu jej z rozwiązaniami konstytucyjnymi dotyczącymi instytucji o zbliżonym statusie.

Główna hipoteza badania jest następująca: Rada Polityki Pieniężnej to szczególny organ państwa o charakterze wykonawczym działający w jego imieniu i na jego rzecz, dlatego że:

- będąc organem NBP działa jako podmiot wewnętrzny banku centralnego i zewnętrzny prowadzący politykę pieniężną;

- kadencyjność i jej skład wpływają na umocnienie pozycji w systemie ustrojowym;

- wysokie wymagania merytoryczne stawiane przed członkami Rady świadczą o jej znaczącej pozycji wśród instytucji władzy wykonawczej.

Pytania badawcze służące weryfikacji hipotezy to: Czy za organ państwa można uznać NBP? Jaki status prawny posiada RPP jako organ banku centralnego w Polsce? Na 
ile obecny model kadencyjności i liczebności członków RPP stanowi umocnienie pozycji w systemie ustrojowym RP? Jak może wpłynąc zmiana liczebności Rady w związku z proponowaną nowelizacją ustawy o NBP? Czy fachowość Rady wpływa na zwiększenie jej pozycji?

\section{Status prawny RPP}

Organy władzy wykonawczej w Polsce nie stanowią jednolitej struktury. W Konstytucji RP władza wykonawcza na szczeblu centralnym została rozdzielona na cztery grupy organów. Zaliczamy do nich Radę Ministrów (RM) i podległe jej organy administracji rządowej, Prezydenta, Narodowy Bank Polski i jego organy oraz Krajową Radę Radiofonii i Telewizji. Organy te względem siebie nie pozostają w stosunku podporządkowania czy nadrzędności (Wojtyczek, 2001, s. 63). Wprowadzony w Polsce podział władzy wykonawczej umożliwia realizację określonych celów. W przypadku NBP podział ten może służyć zwiększeniu efektywności działania aparatu państwowego. Polityka pieniężna prowadzona przez RPP wymaga uniezależnienia od bieżących sporów partyjnych i stworzenia podstaw do realizacji długofalowego rozwoju gospodarczego (Wojtyczek, 2001, s. 65-66).

Określając status prawny RPP, należałoby odnieść się najpierw w tym zakresie do Narodowego Banku Polskiego. Przepisy zawarte w Konstytucji i ustawie o NBP nie dają jasnej odpowiedzi co do statusu banku centralnego w Polsce. Na pewno NBP jest instytucją konstytucyjną. Nie daje to jednak cech organu państwa (Zubik, 2001, s. 33). Cechą organu państwa, jak wskazał w swoim wyroku TK odróżniającą go od organu wewnętrznego, jest możliwość stanowienia decyzji o charakterze władczym w szerokim znaczeniu tego słowa, a więc posiadanie pewnego imperium. Nie stanie się zatem organem państwa podmiot tylko dlatego, że zlecono mu wykonanie funkcji administracji publicznej (Wyrok TK z dnia 1 grudnia 1998 r. przepisy...). Organ państwa to taki podmiot, który został ustanowiony przez prawo, i z mocy prawa wyposażony jest w jemu właściwe kompetencje do władczego działania w imieniu i na rzecz państwa (Zubik, 2002, s. 9-10). O statusie organu państwa decydują pewne charakterystyczne cechy. Podmiot ten powinien być wyodrębniony realnie pod względem organizacyjnym. W dalszej kolejności posiada określony prawnie szczegółowy zakres kompetencji i podmiotowość prawną. Ważną cechą jest możliwość podejmowania działań władczych oraz charakterystyczne zasady funkcjonowania (Trzciński, 1974, s. 58-118). Przedstawione elementy muszą wystąpić jednocześnie. W odniesieniu do NBP nie można precyzyjnie oznaczyć tych cech. Dzieje się tak dlatego, że NBP jest bankiem, a taka struktura organizacyjna wymaga dopiero wskazania organów, których działanie będzie wyrazem woli samej instytucji. W związku z tym Konstytucja RP w sposób wyraźny wskazuje, że organem NBP jest Rada Polityki Pieniężnej. Na gruncie obecnych przepisów zawartych w Konstytucji i regulacjach ustawowych NBP nie może być uznany jako organ państwa (Zubik, 2001, s. 35). Jest on natomiast swoistym podmiotem prawa (Kosikowski, 2002, s. 15-27).

Rada Polityki Pieniężnej to jeden z organów banku centralnego w Polsce (Konstytucja $R P . .$. , art. 227, ust. 2). Analiza przepisów regulujących status prawny Rady pozwala 
na zaliczenie jej do szczególnych organów państwa o charakterze wykonawczym. Przemawiają za tym następujące cechy:

- występuje wyraźne wyodrębnienie RPP, tak w strukturze banku centralnego, jak i w instytucjach państwa;

- działanie w interesie państwa polskiego;

- szczegółowe określenie zakresu zadań i kompetencji;

- działanie w interesie publicznym (Knosola, Stasikowski, 2010, s. 70-71).

Rada Polityki Pieniężnej ustala corocznie założenia polityki pieniężnej, zatwierdza plan finansowy NBP oraz sprawozdanie z działalności NBP, przyjmuje również roczne sprawozdanie finansowe banku centralnego i ustala zasady operacji otwartego rynku (Ustawa z dnia 29 sierpnia 1997 r. o Narodowym..., art. 12, ust. 1 i 2, pkt 4, 5, 6). Wszystkie wymienione działania wskazują, że RPP wykonuje zadania w imieniu i na rzecz państwa polskiego. Są to działania zewnętrzne w stosunku do NBP, co potwierdza jeszcze fakt, że Rada jako organ NBP dokonuje oceny innego organu, jakim jest Zarząd NBP pod kątem jego działalności w zakresie realizacji założeń polityki pieniężnej (Ustawa z dnia 29 sierpnia 1997 r. o Narodowym ..., art. 12, ust. 3). Ocena ta będzie również dotyczyć pośrednio Prezesa NBP, który wchodzi w skład Zarządu.

\section{Model kadencyjności RPP}

Wyróżniamy trzy modele określania kadencyjności w odniesieniu do kolegialnych organów państwa (Zubik, 2005, s. 41-42). W pierwszym modelu mamy do czynienia ze ścisłym ustaleniem kadencji organu. Należy zatem określić sposób powołania i uzupełnienia składu osobowego organu kolegialnego. Cechą tego modelu jest to, że w jednym czasie następuje wygaśnięcie mandatu, niezależnie od tego, kiedy dana osoba została powołana. Dotyczy to Sejmu i Senatu (Konstytucja RP ..., art. 98, ust. 1). Kolejny model określa długość kadencji poszczególnych członków organu kolegialnego, nie mówiąc o kadencyjności samego organu. $Z$ taką sytuacją mamy do czynienia w przypadku Trybunału Konstytucyjnego (TK), gdzie wyraźnie jest określona liczba sędziów oraz długość ich indywidualnej kadencji (Konstytucja RP..., art. 194, ust. 1). Nie trzeba wówczas określać odrębnego trybu postępowania w sprawie uzupełnienia składu osobowego organu. Ten model kadencyjności dotyczy również RPP. W Konstytucji RP została przyjęta koncepcja indywidualnej kadencji poszczególnych członków Rady, a nie RPP jako całości (Konstytucja RP..., art. 227, ust. 5). Sprzeczne z Konstytucją rozwiązanie co do kadencyjności RPP prezentuje ustawa o NBP wprowadzając kadencyjność zbiorową organu (Ustawa z dnia 29 sierpnia 1997 r. o Narodowym ..., art. 13, ust. 7). Ostatecznie niekonstytucyjność rozwiązań zawartych w ustawie o NBP potwierdził Trybunał Konstytucyjny, uznając indywidualną kadencyjność w odniesieniu do każdego członka Rady z osobna (Wyrok TK z dnia 24 listopada 2003 r. konstytucyjność). Warto byłoby jednak dokonać modyfikacji przepisu konstytucyjnego co do kadencyjności RPP stosując jednoznaczny i czytelny zapis, jaki został zastosowany w przypadku TK, a mianowicie „wybieranych indywidualnie przez Sejm” uzupełniając o Senat i Prezydenta RP. Ostatni model kadencyjności odnosi się zarówno do kadencji organu, jak i poszczególnych jej członków. Dotyczy to Krajowej Rady Sądownictwa (Konstytucja RP..., art. 187, ust. 3). 
Pewnym wyjątkiem w stosunku do prezentowanych modeli są konstytucyjne organy kolegialne, gdzie brak odniesienia do liczebności i kadencyjności. Taka sytuacja występuje w Krajowej Radzie Radiofonii i Telewizji (KRRiT). W tym przypadku mamy jedynie informację przez kogo są powoływani członkowie KRRiT (Konstytucja RP ..., art. 214, ust. 1).

Zdaniem M. Zubika usytuowanie RPP w polskim systemie organów państwa daje podstawę do dwóch różnych sposobów wykładni z punktu widzenia modeli kadencyjności, jaka została przewidziana dla Rady (Zubik, 2005, s. 46-47). Pierwsza wykładnia wychodzi z językowego brzmienia przepisu. Zgodnie z nią każda osoba powoływana jest do Rady na okres 6 lat. Taki zapis w sposób jednoznaczny określa indywidualną kadencję członków Rady. Zatem celem ustrojodawcy było utworzenie organu, którego członkami są osoby pełniące funkcje w określonym czasie. Druga wykładnia wychodzi z założenia, że określenie w Konstytucji kadencji trwającej sześć lat nie przesądza tego, że sama Rada jako organ kolegialny państwa nie mogłaby być ukształtowana na zasadzie kadencyjności. Zapis konstytucyjny wyznaczałby jedynie minimum organizacyjnych wymogów i wskazywałby, że kadencja poszczególnych członków ma wynosić 6 lat. Oznacza to, że dopuszczalne jest $\mathrm{w}$ drodze ustawy określenie sześcioletniej kadencji Rady jako takiej. Wówczas jednak należałoby wkomponować w ten system mechanizm uzupełniania składu do końca kadencji Rady. Przyjęcie tej metody stwarza szansę, aby na drodze ustawy zróżnicować moment rozpoczęcia kadencji przez osoby wchodzące w skład Rady. Zróżnicowanie składu Rady pozwoliłoby na uniknięcie jednoczesnej wymiany całego jej składu, co zmniejszyłoby w sposób znaczący niepewność w polityce pieniężnej. Pozwoliłoby to również na zapewnienie funkcjonalnej i instytucjonalnej ciągłości tego organu NBP, likwidując jednocześnie ryzyko przerwy międzykadencyjnej. Całkowita wymiana składu RPP sprawia, że pojawia się ryzyko niespójności decyzji w kolejnych kadencjach. Może to skutkować utratą kapitału intelektualnego i pamięci instytucjonalnej. Nie można bowiem w sposób prosty przekazać tych elementów wszystkim nowym osobom, które zasiądą w RPP (Departament Rozwoju Rynku Finansowego, Notatka...). Wprowadzenie mechanizmu uzupełniania składu Rady może skrócić czas uczenia się prowadzenia polityki pieniężnej przez jej nowych członków. Będą oni mogli skorzystać z doświadczenia zasiadających już w Radzie osób. Proponowane rozwiązanie jest ważne z politycznego punktu widzenia. Przy zastosowaniu mechanizmu uzupełniania składu Rady można zapobiec dominacji politycznej partii, dysponującej w danej kadencji większością w Sejmie i Senacie. Działanie takie byłoby wzmocnieniem dalszego uniezależnienia kształtu polityki pieniężnej od wpływu organów państwa i ich wyborczego kalendarza. Nastąiłoby w ten sposób pewne uniezależnienie się Rady od politycznego cyklu wyborczego. Proponowana zmiana ustawy o NBP nawiązuje do omawianego wyżej modelu. Zakłada ona, że na miejsce każdych dwóch członków Rady wybieranych przez Sejm, Senat i Prezydenta, których kadencja kończy się w 2022 r. nie powołuje się nowych członków. Z projektu wynika, że po upływie kadencji w $2022 \mathrm{r}$. nikt nie zostanie powołany do Rady (Projekt zmiany ustawy o NBP...). Pojawia się tutaj jednak pewna wątpliwość zgodności z Konstytucją RP. Mianowicie podmioty uprawnione do wyboru członków Rady nie będą tego dokonywać równo co 6 lat jak mówi Konstytucja RP (Konstytucja $R P$, art. 227, ust. 5). Jeżeli po upływie kadencji w 2022 r. nikt nie zostanie powołany, 
a tak wynika z propozycji zmiany ustawy o NBP, to okres ten wydłuży się powyżej 6 lat i w ten sposób może dojść do złamania zapisu konstytucyjnego.

\section{Funkcje kadencyjności}

Dzięki kadencyjności realizowane są dwie funkcje: legitymizacyjna i autonomii działań. Ma ona zapewnić zmienność składu osobowego danego organu. Wiąże się to z demokratycznym sposobem sprawowania funkcji publicznych. Daje to również możliwość odnowienia legitymizacji społecznej danym osobom. Polega ona na uznaniu, że sprawujący władzę i sposób sprawowania tej władzy w opinii społecznej jest uznany za właściwy i godny akceptacji. Sprawdzianem dla legitymizacji społecznej władzy są masowe i spontaniczne działania społeczeństwa ujawniające się w demonstracjach, wiecach czy akcjach nieposłuszeństwa obywatelskiego. Innym aspektem legitymizacji jest legitymizacja prawna oznaczająca legalizację władzy. Oznacza to, że wykonywana ona jest zgodnie z obowiązującym prawem zawartym w konstytucji i ustawach (Sagan, Serzhanova, 2011, s. 96-97). Władza legitymowana społecznie jest również legitymowana normatywnie. Dochodzi bowiem do sytuacji, w której legitymizacja normatywna wzmacnia legitymizację społeczną. Natomiast władza legitymowana normatywnie poparta społecznie uzyskuje mocny fundament. W sytuacji kiedy władza jest legitymowana tylko normatywnie, a nie posiada uznania społecznego dochodzi do erozji norm, na których władza ta do tej pory opierała się. Podstawowe więc znaczenia dla struktur władczych ma legitymizacja społeczna, natomiast legitymizacja normatywna jest jej pochodną (Winczorek, 2011, s. 53-54). Kadencja zapewnia pewien horyzont wykonywania kompetencji przypisanych danemu organowi i pewną cykliczność poddawania kontroli sposobu zajmowania stanowisk. Zakaz reelekcji, jaki może towarzyszyć kadencyjności, zabezpiecza aby dane stanowisko nie zostało spersonalizowane. Druga funkcja kadencyjności związana jest $\mathrm{z}$ możliwością niezależnego wykonywania zadań danego organu w ramach przypisanej kadencji. Wzmocnieniem tej niezależności jest postulat ponoszenia odpowiedzialności za podejmowane decyzje w ramach sprawowanego stanowiska z prawnymi gwarancjami niezależności. Istnieje jednak pewne zagrożenie, w przypadku gdy indywidualna kadencja nie określa liczby członków organu kolegialnego może nastapić dołączenie do istniejącego składu nowych osób w trakcie trwania kadencji (Zubik, 2005, s. 41).

Odnosząc powyższe zapisy do RPP należy stwierdzić, że kadencyjność Rady daje możliwość zmiany jej składu osobowego, a wzmacnia to jednokadencyjność. W jej przypadku nie można mówić o odnowieniu legitymizacji społecznej, ponieważ członkiem Rady można być tylko jeden raz. Członkowie RPP uzyskują legitymizację społeczną w sposób pośredni. Związane jest to z trybem wyboru Rady (Konstytucja RP, art. 227, ust. 5). Legitymizacja społeczna w przypadku Rady jest również legitymowana normatywnie przez zapisy konstytucyjne i ustawowe. W przypadku RPP zakaz reelekcji w sposób zdecydowany zabezpiecza, aby dane stanowisko nie zostało personalnie powiązane z określoną osobą. Istnieje również niebezpieczeństwo dołączenia do składu nowych osób w trakcie trwania kadencji. Wynika to z braku doprecyzowania tej kwestii w Konstytucji RP. Mówi ona bowiem, że skład Rady jest wybierany w równej liczbie 
przez Sejm, Senat i Prezydenta RP. Przepis ten nie wskazuje konkretnie ilu członków Rady powołuje każdy z tych organów. Jest to doprecyzowane przez ustawę o NBP. Jednak jak wiadomo polska konstytucja należy do grupy tzw. konstytucji sztywnych, co wiąże się z pewnymi utrudnieniami związanymi z jej zmianą. Wprowadzenie do Konstytucji RP konkretnego zapisu co do ilości członków powoływanych przez wymienione organy władzy zmniejszyłoby możliwość dołączenia nowych członków, a tym samym uodporniło na ewentualne manipulacje składem Rady. Przepisy, jakie wprowadza ustawa o NBP, można zmienić w łatwiejszy sposób.

\section{Zmiany składu (liczebności) RPP}

Obecnie RPP składa się z Przewodniczącego i 9 członków. Kształtując skład osobowy Rady ustrojodawca dążył do zachowania równowagi sił, zachowując zasadę trójpodziału władzy. Przyczynia się to do utrzymania apolityczności tego organu (Banaszak, 2009, s. 963). Zgodnie z ustawą o NBP Sejm, Senat i Prezydent RP wybierają po trzy osoby do Rady. Zatem skład RPP jest powoływany na zasadzie parytetowej. Podczas sprawowania swojej funkcji członek RPP nie może zajmować żadnych stanowisk i podejmować działalności zarobkowej lub publicznej poza pracą naukową, dydaktyczną lub twórczością autorska, a za zgodą Rady, wyrażoną w drodze uchwały, może uzyskać zgodę na udział w organizacjach międzynarodowych. Istotną regulację ustawodawcy z punktu widzenia organu państwa, jakim jest RPP, stanowi obowiązek zawieszenia działalności w partii politycznej lub związku zawodowym przez członka Rady na okres kadencji pod rygorem odwołania z Rady (Ustawa z dnia 29 sierpnia 1997 r. o Narodowym ..., art. 14, ust. 1 i 2). W związku z tym, że RPP to szczególny organ państwa, należałoby ten zapis zaostrzyć do obowiązku rezygnacji z członkostwa w partii politycznej czy związku zawodowym. Pozwoliłoby to na zmniejszenie uzależnienia się od dyrektyw partyjnych, często szkodliwych dla gospodarki, a wpisujących się w polityczny cykl wyborczy. Kategoryczny zakaz przynależności do partii politycznej czy związku zawodowego dotyczy natomiast Prezesa NBP (Konstytucja RP, art. 227, ust. 4), który jest jednocześnie Przewodniczącym RPP.

Nowelizacja ustawy o NBP proponuje zmianę składu RPP do 7 osób - 6 członków Rady i Przewodniczący. Takie rozwiązanie nie budzi wątpliwości co do zgodności z Konstytucją RP, bowiem uprawnione do tego podmioty powołują po równej liczbie członków Rady. Zapis ustawowy precyzuje tą liczbę do trzech. Kadencja obecnej Rady kończy się w 2016 r. Rada przejściowo ma być zwiększona do 12 osób, dlatego też w 2019 r. każdy z uprawnionych organów powoła do niej po jednym członku. W ten sposób zostanie zrealizowany warunek wymiany Rady co trzy lata.

Manipulacja ilościowym składem Rady polegająca na jej zwiększeniu do 12 osób, a docelowo zmniejszeniu do sześciu ma swoje dobre i złe strony. Powiększenie Rady może spowodować większą przychylność w stosunku do rządu, a zatem może to być wybór bardziej polityczny. W takiej sytuacji może zaistnieć rozbieżność poglądów co do prowadzenia polityki pieniężnej. Zmniejszenie Rady do 6 osób stwarza możliwość większego oddziaływania politycznego przez wywoływanie presji w przeciwieństwie do ich większej liczby. Bardziej rozproszona Rada może sprzyjać podejmowaniu decyzji zgodnych z logiką gospodarczą. 


\section{Wymogi merytoryczne czlonków RPP}

Rada Polityki Pieniężnej to organ kolegialny, co wiąże się z koniecznością współpracy zasiadających tam osób. Kolegialność w przypadku Rady jest korzystnym rozwiązaniem, bowiem podejmowanie decyzji związanych z realizacją polityki pieniężnej państwa jest rozstrzygane przez dyskusję. Pozwala to na uwzględnienie różnych punktów widzenia i dojścia do konsensusu. Uzyskanie właściwego konsensusu przez organ kolegialny będzie zależeć od wymogów merytorycznych stawianych jego członkom. Wysokie wymagania merytoryczne postawiono członkom RPP. Dotyczą one szczególnej wiedzy z zakresu finansów. Należałoby jednak doprecyzować pojęcie "osoby wyróżniające się wiedzą z zakresu finansów" uwzględniając odpowiednie teoretyczne i praktyczne przygotowanie poparte doświadczeniem w instytucjach sektora finansowego. Dziwnym rozwiązaniem wydaje się brak takich wymogów w stosunku do Prezesa NBP, który jest Przewodniczącym RPP. Mamy więc do czynienia ze zróżnicowaniem wymagań względem członków Rady. Może być to przyczyną konfliktów i zmniejszyć efektywność działania kolegialnego organu, jakim jest RPP, przejawiającą się w braku uzyskania konsensusu. Na takie zachowania Rada nie powinna sobie pozwolić ze względu na możliwość utraty zaufania do jej decyzji ze strony podmiotów gospodarczych.

Z podobnymi wymogami dotyczacymi wysokich kwalifikacji tylko z zakresu prawa spotykamy się w stosunku do członków Trybunału Konstytucyjnego (Konstytucja RP, art. 194, ust. 1). TK i RPP to dwie instytucje, przed którymi postawiono tak wysokie wymagania. Upodobnienie wymogów z TK co do kwalifikacji świadczy o wyjątkowej pozycji Rady w odniesieniu do innych organów państwa (Kraś, 2013, s. 88).

W stosunku do pozostałych osób zajmujących wysokie stanowiska w państwie takich wymogów nie spotykamy. Nie ma ich w odniesieniu do tak ważnych stanowisk jak Prezes Rady Ministrów, Ministrowie, Prezes Najwyższej Izby Kontroli (NIK) czy członków KRRiT. Takie potraktowanie kryterium kwalifikacji czyni wymienione instytucje bardziej politycznymi.

Pewną wadą organu kolegialnego mogą być znaczne koszty jego funkcjonowania. Tak jest w przypadku Rady, która liczy bez Przewodniczącego 9 osób. Członek RPP otrzymuje wynagrodzenie równe wynagrodzeniu wiceprezesa NBP. Kształtuje się ono na poziomie powyżej 20 tys. zł. Nowelizacja ustawy o NBP proponuje docelowo zmniejszenie członków Rady do 6 osób, ale przejściowo przewiduje jej zwiększenie do 12. Należy jednak zaznaczyć, że warto jest ponieść koszty, jakie niesie za sobą funkcjonowanie takiego organu kolegialnego, jakim jest RPP, aby zachęcić do pracy w niej osoby posiadające wymagane kwalifikacje sprecyzowane przez Konstytucję RP. Istnieje bowiem duże ryzyko, że w przypadku znacznych ograniczeń kosztowych działania Rady mogą się do niej dostać osoby ze słabszym przygotowaniem z zakresu finansów, co wpłynęłoby na jakość podejmowanych decyzji dotyczących polityki pieniężnej państwa. Poza tym stosowne wynagrodzenie zwiększa gwarancje samodzielności w podejmowaniu decyzji, co powoduje że są one podejmowane zgodnie z logiką gospodarczą. Pozwala to również członkowi RPP na zmniejszenie wpływów politycznych na jego decyzje. Błędnie lub nadmiernie upolitycznione decyzje co do polityki pieniężnej mogą spowodować o wiele większe koszty w odniesieniu do całej gospodarki. 
Kolejną wadą licznego organu kolegialnego może być zmniejszenie poczucia odpowiedzialności za podjęte decyzje, ponieważ rozkłada się ona na osoby w nim zasiadające. Nie ma natomiast w przypadku RPP problemu z ustaleniem osób, które podejmują stosowną uchwałę, ponieważ odbywa się to przez imienne głosowanie. Zwiększa to również poczucie odpowiedzialności za podjętą uchwałę, bowiem mamy dokładne wskazanie jaki był rozkład imienny podczas głosowania (Wyniki głosowania Członków...).

Umocnieniu pozycji osób wybranych do RPP zgodnie z wymogami fachowości sprzyja sposób odwoływania ich ograniczony do określonych sytuacji. Określenie sytuacji odwołania wpływa na decyzję odnośnie zgody na udział w pracach Rady. Takie doprecyzowanie sytuacji pozwala również na poczucie stabilności udziału w pracach Rady ze strony członka RPP. Może on być odwołany przez organ powołujący go w następujących przypadkach: zrzeczenia się funkcji, choroby trwale uniemożliwiającej sprawowanie funkcji, skazania prawomocnym wyrokiem sądu za popełnienie przestępstwa, złożenia niezgodnego z prawdą oświadczenia lustracyjnego, stwierdzonego prawomocnym orzeczeniem sądu, gdy na okres kadencji nie zawiesi członkostwa w partii lub związku zawodowym (Ustawa z dnia 29 sierpnia 1997 r. o Narodowym..., art. 13, ust. 5). Wydaje się jednak, że należałoby sprecyzować szczegółowe przesłanki co do odwołania z powodu choroby. Nie określono jak długo ma trwać choroba i jaki organ mógłby stwierdzić niewypełnianie tej przesłanki. Jest to kryterium niezwykle ocenne i obiektywnie trudne do weryfikacji. Właściwe w tym kontekście byłoby wprowadzenie horyzontu czasowego np. okresu 5 miesięcy, w którym członek RPP nie wypełnia swoich obowiązków z powodu choroby. Należałoby również uznać, że skutkiem długotrwałej choroby ma być nie trwałe, ale całkowite wyłączenie danej osoby od wykonywania obowiązków członka Rady. Będzie to dotyczyć sytuacji, gdy dana osoba nie tylko, że nie jest w stanie brać udziału w posiedzeniu Rady, ale przede wszystkim nie jest w stanie rozeznać materii, którą się zajmuje (Stanisławiszyn, s. 154-155).

\section{Zakończenie}

Przedstawiona we wstępie hipoteza mówiąca, że Rada Polityki Pieniężnej to szczególny organ państwa o charakterze wykonawczym działający w jego imieniu i na jego rzecz została zweryfikowana pozytywnie. Na jej rzecz przemawiają następujące argumenty. RPP to jeden z organów banku centralnego w Polsce. W przeciwieństwie do niego posiada ona status organu państwowego. Przekłada się to na jej wyjątkową pozycję. Rada jest wewnętrznym organem NBP i jednocześnie samodzielnym organem państwa odpowiedzialnym za prowadzenie polityki pieniężnej. Jako wewnętrzny organ NBP ma istotny wpływ na jego funkcjonowanie, co znajduje potwierdzenie w ocenie działalności Zarządu NBP w zakresie realizacji założeń polityki pieniężnej. Założenia tej polityki przedstawia do wiadomości Sejmowi równocześnie z przedłożeniem przez Radę Ministrów projektu ustawy budżetowej. Konstytucja jednak nie precyzuje w jaki sposób te założenia mają być przekazane. Nie pozwala to na ustosunkowanie się Sejmu do tych założeń oraz uniemożliwia polityczną kontrolę. Taki sposób procedowania założeń podkreśla silną zewnętrzną pozycję Rady. Zmiany założeń polityki pieniężnej może dokonywać jedynie sama Rada, a tym samym nie może ona być związana z postanowieniami zawartymi w ustawie budżetowej. 
Indywidualna kadencja oraz zakaz reelekcji zabezpieczaja, aby członkostwo w Radzie nie zostało spersonalizowane. Członkiem RPP można być przez okres sześciu lat. Jest to stosunkowo długi czas w porównaniu z innymi organami władzy państwowej. Długa kadencja zapewnia odpowiedni horyzont czasowy pozwalający na realizację przypisanych kompetencji. Wpływa to również na podejmowanie niezależnych decyzji.

Obecny kształt Rady pod względem liczebności wydaje się optymalny. Zasada parytetu wyboru członków Rady przyczynia się do zachowania apolityczności. Zgodnie z nią w Radzie znajdują się przedstawiciele wybrani przez Sejm, Senat i Prezydenta RP. Mamy więc w niej reprezentację władzy ustawodawczej i wykonawczej. Koncentrację członków Rady na prowadzeniu polityki pieniężnej państwa zapewniają zakazy, jakie należy spełnić, aby znaleźć się w jej składzie. Wzmocnieniem tych wymogów byłby konstytucyjny przepis jak w przypadku Prezesa NBP mówiący o zakazie przynależności do partii politycznej czy związku zawodowego. Regulacja ustawowa mówi tylko o obowiązku zawieszenia członkostwa. Wprowadzenie takiej modyfikacji przyczyniłoby się do wzmocnienia apolityczności tego organu państwa.

Propozycja zmiany ustawy o NBP mówi o jej docelowym zmniejszeniu do sześciu osób, a w okresie przejściowym dokonuje zwiększenia do 12. Niesie to ze sobą dobre i złe strony. Zwiększenie Rady może być związane z wyborem politycznym zwiększającym przychylność w stosunku do rządu. Rozproszenie składu kolegialnego wpływa na rozbieżność poglądów co do prowadzenia polityki pieniężnej. Natomiast zmniejszenie Rady do proponowanego ilościowego składu daje możliwości większego oddziaływania politycznego.

Istotnym argumentem co do zmniejszenia Rady byłaby kwestia kosztów jej utrzymania. Obecnie są one wysokie, a w przypadku proponowanego okresu przejściowego będą jeszcze większe. Ze względu na optymalność obecnego składu RPP koszty utrzymania powinny pozostać na tym samym poziomie. Istnieje bowiem duże ryzyko, że ich zmniejszenie mogłoby wpłynąć na fachowość oraz zmniejszenie gwarancji samodzielności Rady w podejmowaniu decyzji zgodnych z logiką gospodarczą.

Wysokie wymogi co do kwalifikacji członków Rady związane z wyróżniającą wiedzą z zakresu finansów czynią z niej szczególny organ państwa. Podobne wymogi stawiane są tylko członkom TK, a dotyczą one wyróżniającej wiedzy prawniczej. Należałoby jednak dokładniej sprecyzować chociażby przez regulacje ustawowe co oznacza wyróżniająca wiedza z zakresu finansów. Powinna ona uwzględniać odpowiednie teoretyczne i praktyczne przygotowanie poparte doświadczeniem w instytucjach sektora finansowego. Taka regulacja spowodowałaby dalsze odpolitycznienie Rady. Niekorzystny jest również brak wymagań co do fachowości w odniesieniu do Prezesa NBP, który jest jednocześnie Przewodniczącym RPP. Powoduje to zróżnicowanie wymogów merytorycznych w Radzie, co może doprowadzić do konfliktów, zmniejszyć efektywność jej działania i doprowadzić do utraty zaufania ze strony podmiotów gospodarczych.

Pewnym osłabieniem hipotezy jest niebezpieczeństwo zwiększenia liczebności Rady, co może wpłynąć na zmniejszenie pozycji RPP jako organu państwa. Taki stan rzeczy wynika z braku doprecyzowania tej kwestii w Konstytucji RP. Skład Rady jest wybierany w równej liczbie przez Sejm, Senat i Prezydenta RP. W celu likwidacji prób zwiększania składu rady należałoby poprzez regulację konstytucyjną doprecyzować ilu członków Rady może powołać każdy z tych organów. 
Argumentem osłabiającym hipotezę jest brak odpowiednich kompetencji prawotwórczych RPP. Rada może wydawać uchwały jako akty wewnętrzne wobec podległych jej jednostek. Mają one charakter aktów wykonawczych powszechnie obowiązujących odnoszących się do banków komercyjnych. W oparciu o regulacje konstytucyjne RPP nie powinna stanowić takiego aktu. Dlatego w Konstytucji powinien znaleźć się przepis dający Radzie możliwość wydawania rozporządzeń, a ustawa precyzowałaby czego mogą one dotyczyć. Co prawda na podstawie wyroku TK w przypadku Rady wykorzystano koncepcję podległości funkcjonalnej w relacji NBP - banki komercyjne. Ma ona jednak ograniczoną legitymizację prawną.

Rada Polityki Pieniężnej to szczególny organ państwa mający kluczowe znaczenie dla prowadzenia polityki pieniężnej. Nie jest on hierarchicznie podporządkowany żadnemu organowi władzy państwowej. Jest zatem jednym z niezależnych ośrodków władzy publicznej.

\section{Bibliografia}

Banaszak B. (2009), Konstytucja Rzeczpospolitej Polskiej. Komentarz, C.H. Beck, Warszawa.

Knosola E., Stasikowski R. (2010), Status Narodowego Banku Polskiego w systemie organów państwa, „Przegląd Sejmowy”, nr 1(96).

Konstytucja RP z dnia 2 kwietnia 1997 r. (Dz. U. Nr 78, poz. 483 ze zm.).

Kosikowski C. (2002), Pozycja Narodowego Banku Polskiego i jego organów w prawie polskim (stan obecny i postulaty na przyszłość), „Państwo i Prawo”, nr 11(681).

Kraś I. (2013), Rola Narodowego Banku Polskiego w polityce gospodarczej Polski w latach 1997-2010, AJD, Częstochowa.

Notatka dla Ministerstwa Finansów dotyczqca projektu zatożeń projektu ustawy o zmianie ustawy o Narodowym Banku Polskim oraz niektórych ustaw (2013), Departament Rozwoju Rynku Finansowego, Warszawa, dnia 25 października.

Projekt zmiany ustawy o NBP z dnia 22 grudnia $2014 \mathrm{r}$.

Sagan S., Serzhanova V. (2011), Nauka o państwie wspótczesnym, LexisNexis, Warszawa.

Stanisławiszyn P. (2011), Powołanie i odwołanie Prezesa Narodowego Banku Polskiego w Konstytucji Rzeczpospolitej Polskiej i ustawie o Narodowym Banku Polskim, „Ekonomia i Prawo”, t. VII.

Trzciński J. (1974), Pojęcie konstytucyjnego organu państwa socjalistycznego, Warszawa.

Ustawa z dnia 29 sierpnia 1997 r. o Narodowym Banku Polskim (Dz. U. Nr 140, poz. 938, ze zm.).

Winczorek P. (2011), Nauka o państwie, Liber, Warszawa.

Wojtyczek K. (2001), Władza wykonawcza w Polsce: dualistyczna czy wieloczłonowa?, „Państwo i Prawo", nr 12(670).

Wyniki głosowania członków RPP z dnia 4.03.2015 r. http://www.nbp.pl/home.aspx?f=/polityka_pieniezna/dokumenty/glosowania.html.

Wyrok TK z dnia 1 grudnia 1998 r. przepisy przyznajace Marszałkowi Sejmu prawo nadawania statutu Najwyższej Izbie Kontroli oraz powoływania wiceprezesów i członków Kolegium NIK, syg. K 21/98, OTK ZU, nr 7/1998.

Wyrok TK z dnia 24 listopada 2003 r. konstytucyjność niektórych przepisów ustawy o Narodowym Banku Polskim, dotyczacych długości trwania kadencji członków Rady Polityki Pieniężnej, syg. 26/03, OTK ZU, nr 9a/2003.

Zubik M. (2005), Powołanie członków Rady Polityki Pieniężnej w świetle zasady kadencyjności oraz działalności organów państwa, „Przegląd Sejmowy”, nr 4(69). 
Zubik M. (2002), Wybrane problemy dotyczace statusu prawnego Marszałka Sejmu, „Przegląd Sejmowy", $\mathrm{nr} 4$.

Zubik M. (2001), Narodowy Bank Polski (Analiza konstytucyjno-ustrojowa), „Państwo i Prawo”, nr 6.

\title{
The Monetary Policy Council as a special state organ
}

\begin{abstract}
Summary
The paper deals with the topic of the Monetary Policy Council. The main aim of this research paper is to analyze the institutional position of the Council. The first part focuses on the definition of the Monetary Policy Council's status. The next part concerns the model of the term of office and personal composition of the Council. In this context, proposals for changes are presented which are included in the project of the new law on the National Bank of Poland. A significant part of the paper describes the conceptual requirements for the members of the MPC. They emphasize the importance of the Council in comparison with other state bodies. The ending presents the conclusion that the Monetary Policy Council is a state organ of special importance. The author indicates the need for certain changes to reinforce the actions of the Monetary Policy Council, especially the need to regulate the number of members of the MPC who should be appointed by the relevant bodies and authorities by means of the Constitution. Additionally, the issues concerning legislative competence must be discussed as well.
\end{abstract}

Key words: state institutions, central bank, economic policy 
